\title{
1 Investigation of Diverse Bacteria in Cloud Water at Mt. Tai,
}

\section{China}

3 Caihong $\mathrm{Xu}^{\mathrm{a}}$, Min $\mathrm{Wei}^{\mathrm{a}}$, Jianmin Chen ${ }^{\mathrm{a}, \mathrm{b}, *}, \mathrm{Xiao} \mathrm{Sui}^{\mathrm{a}}$, Chao Zhu ${ }^{\mathrm{a}}$, Jiarong $\mathrm{Li}^{\mathrm{a}}$, Lulu

4 Zheng ${ }^{\mathrm{b}}$, Guodong Sui ${ }^{\mathrm{b}}$, Weijun Li $^{\mathrm{a}}$, Wenxing Wang ${ }^{\mathrm{a}}$, Qingzhu Zhang ${ }^{\mathrm{a}}$, Abdelwahid

$5 \quad$ Mellouki $\mathrm{i}^{\mathrm{b}, \mathrm{c}}$

6 a Environment Research Institute, School of Environmental Science and Engineering,

7 Shandong University, Ji'nan 250100, China

8 b Shanghai Key Laboratory of Atmospheric Particle Pollution and Prevention (LAP),

9 Fudan Tyndall Centre, Department of Environmental Science \& Engineering, Fudan

10 University, Shanghai 200433, China

$11{ }^{\mathrm{c}}$ Institut de Combustion, Aérothermique, Réactivité et Environnement, CNRS, 45071

12 Orléans cedex 02, France

$13{ }^{*}$ Corresponding Author

14 E-mail address: jmchen@sdu.edu.cn (J. M. Chen), or jmchen@fudan.edu.cn. 
Bacteria are abundant in atmospheric water phase with the potential to influence

17 atmospheric processes and human health, yet relatively little information is known

18 about the bacterial characteristics at high altitudes. Here we investigated the bacterial

19 community by high throughput sequencing in 24 cloud water samples collected from

20 September 26 to October 31, at the summit of Mt. Tai $\left(36^{\circ} 15^{\prime} \mathrm{N}, 117^{\circ} 06^{\prime} \mathrm{E}, 1534 \mathrm{~m}\right.$

21 a.s.l) in China. Diverse bacterial population were identified and the gram-negative

22 bacteria contributed the majority of total bacteria including Proteobacteria (81.6\%) and

23 Bacteroidetes (3.9\%), followed by gram-positive bacteria Firmicutes $(7.1 \%)$ and

24 Actinobacteria (2.3\%). These gram-negative taxa mainly inhabited in leaf-surface and

25 cold environments. Meanwhile bacteria involved in the cloud condensation nuclei and

26 ice nuclei formation were observed such as Sphingomonas (6.7\%), Pseudomonas

$27(4.1 \%)$, and Bacillus (1.1\%). In addition, Sphingmonas was more active than that in

28 daytime and participated in the cloud chemistry process. Meanwhile $\mathrm{O}_{3}$ and $\mathrm{SO}_{2}$

29 critically contributed to the variation of bacterial community. It is the first report on the

30 bacterial community structure of cloud water over Asian area. Our results can serve as

31 an important reference for environmental scientists, and biologists.

32 Keywords: Cloud water; Bioaerosol; Bacterial community; 16S rRNA sequencing 


\section{Introduction}

Airborne bacteria have gained growing attentions from scholars, mainly focusing on their potential roles in atmospheric chemistry and nucleation process such as biotransformation of organic matter, carbon cycling, photochemical reactions, and cloud formation (Amato et al., 2007a; Bowers et al., 2009; Delort et al., 2010; Despres et al., 2012; Šantl-Temkiv et al., 2015; Smets et al., 2016). These microbes also provide a medium for the spread of diseases through potential pathogens and allergens (Bowers et al., 2012; Cao et al., 2014). The previous findings have reported that these bacteria at high altitudes are metabolic active and reproductive even under a hostile supercooled environment (Smets et al., 2016). Increasing evidence stated that the active bacteria isolated from different cloud type (continental, marine, and anthropogenic cloud) can link to the photochemistry and biological reactions (Delort et al., 2010; Vaïtilingom et al., 2012). While the bacterial characteristics obtained from orographic clouds have not been fully studied.

7 Orographic clouds are generated by the forced lift of air mass under a special topographic feature, in particular mountain regions. The air mass can quickly cool down adiabatically with the increase of altitudes, and then raise the relative humidity up to $100 \%$, a fact that is likely to influence the bacterial community (Kourtev et al., 2011). So far the research at the high altitudes were restricted, mainly focused on the bacterial ice nucleation activity, concentration and functions on the nucleation process (Matthias-Maser et al., 2000; Birgit et al., 2001; Marinoni et al., 2004; Vaïtilingom et al., 2012; Joly et al., 2013; Amato et al., 2015). Researches on the total bacterial community were rare due to the limited measurement technique. Vaïtilingom et al. (2012) investigated the microbial population in cloud water via cultured method at the 
puy de Dôme Mountain (about 1465m), France. Yet, this method restricted on the cultured bacteria which contributed to less than $1 \%$ of the total bacteria (Amato et al., 2007a; Hill et al., 2007). With the advances in high-throughput sequencing, many researchers employed this technology to characterize the taxonomic identification of airborne bacteria at phylum, class, order, family, genus, and species levels. Bowers et al. (2009) presented the dominant Proteobacteria and Bacteroidetes which occupied about $93 \%$ of total bacteria by tagged pyrosequencing, and evaluated their potentials to act as ice nuclei at Mt. Werner (about 3200m), USA. Afterward at the same sampling site, they found the temperature affected the seasonal variation of airborne community dramatically (Bowers et al., 2012). DeLeon-Rodriguez et al. (2013) revealed an important impact of hurricanes on the bacterial community in the middle to upper troposphere across the United States. Maki et al. (2015) reported the metrological influence on the bioaerosol collected at three different altitudes $(10 \mathrm{~m}, 1000 \mathrm{~m}$, and $3000 \mathrm{~m}$ ) in downtown atmosphere over the Noto Peninsula, Japan. However, the relevant researches were mostly conducted in America and Asia based on the aerosol samples, limited eyes concentrated on the bacterial population in cloud water across Asian region. Hence, it is essential to advance the knowledge, especially in the fast developing countries. During 2013, 2014 and 2015, Northern China experienced serious air pollution associated with the inadequate use of energy in the transport, domestic, and industrial sectors. North China Plain is the region with the worst air pollution in China, including Beijing, Tianjin, Shijiazhuang, Jinan, and Qingdao. Mt. Tai $\left(36^{\circ} 15^{\prime} \mathrm{N}, 117^{\circ} 06^{\prime} \mathrm{E}, 1534 \mathrm{~m}\right.$ a.s.1), locates on the summit of North China Plain, covers a total area of approximately 426 square kilometers, faces the east sea and back on the yellow river to the west. It is frequently attacked by cloud events, especially in March, April, June, July, October, and November (Guo et al., 2012; Liu et al., 2012; 
82 Wang et al., 2011). The special terrain is conducive to the formation of orographic 83 clouds. Across this area, researchers have described the physicochemical properties of cloud water, e.g. pH, conductivity, water soluble inorganic ions, sulfur (IV), total organic carbon, PAHs, heavy metal elements and organic acids (Li et al., 2011a; Li et al., 2011b; Li et al., 2013; Ervens et al., 2015; Li et al., 2016), and did not pay attentions on the airborne bacterial characteristics.

Herein, we used high-throughput sequencing to characterize the bacterial communities in cloud water collected at Mt. Tai, China, with environmental factors $\left(\mathrm{PM}_{2.5}, \mathrm{SO}_{2}, \mathrm{O}_{3}, \mathrm{CO}\right.$, and $\left.\mathrm{NO}_{2}\right)$ monitored in real time. The unique dataset fulfill the gap of the comprehensive analysis of bacterial communities at a high altitude site across the Asian area and allow us to address the following hypothesis: what characteristics the bacterial community in cloud water at high altitude exhibited? Does the bacterial diversity and community structure varied between daytime and nighttime? Does the bacterial community structure changed across different environmental factors?

\section{Material and methods}

\subsection{Cloud Water Collection and Environmental Factors}

Cloud water is formed by water condensation of atmospheric particles under supersaturation environment (Martinsson et al., 1999). We determined the cloud events based on the duration. The cloud process lasted more than one hour in a day was considered as one cloud event. For each event, continuous samples were collected once volumes got enough of $100 \mathrm{~mL}$. As shown in Table 1, Mt. Tai experienced 10 cloud events, and 24 samples were collected from September 26 to October 31, 2014. The cloud water were sampled on a bank of Teflon strands at $24.3 \mathrm{~m}^{3} / \mathrm{min}$ by a fan situated 
106 (Collett et al., 2001; Wang et al., 2014; Modini et al., 2015). Collected samples flowed

107 from the Teflon strands, through Teflon tube into a polyethylene bottle finally. The

108 theoretical 50\% cut-off size was equivalently drop diameter of $3.5 \mu \mathrm{m}$. To avoid the

109 artificial contamination, the Teflon strands and tube were kept in sterile criteria and the 110 polyethylene bottles were pretreated with $75 \%$ ethanol before sampling. The $\mathrm{pH}$ and

111 conductivity of the samples were measured immediately using a pH/conductivity

112 analyzer (pH/COND/TEMP METER, 6350). An automatic meteorological station

113 (JZYG, PC-4) and Synchronized Hybrid Ambient Real-Time Particulate monitor

114 (SHARP, Model 5030, Thermo Fisher Scientific, USA) were used to measure the

115 environmental temperature and $\mathrm{PM}_{2.5}$ mass concentration in real time. Trace gases $\mathrm{SO}_{2}$,

$116 \mathrm{NO}_{2}$, and $\mathrm{O}_{3}$ in atmosphere were monitored by Model 42C, Model 43C, and Model 49C

117 (Thermo Scientific, USA). CO was monitored by an API 300E analyzer (Teledyne,

118 USA). The Hybrid Single Particle Lagrangian Integrated Trajectory (HYSPLIT) model

119 was employed to create the twenty-four hours backward trajectories for air mass

120 transport pathway arriving at $1534 \mathrm{~m}$ above ground level. The detail information about

121 the sampling time and environmental factors were shown in Table 1 . In order to identify

122 the day/night variation of bacterial community, we specified daytime sampling from 7

123 a.m. to 7 p.m. Beijing time and nighttime sampling from 7 p.m. to the next day 7 a.m.

124 Beijing time. There were twelve samples sampled from daytime and nighttime.

\subsection{DNA Extraction and PCR Amplification}

126 Firstly, each sample was centrifuged for $3 \mathrm{~min}$ at $3000 \mathrm{rpm}$, then discarded the 127 supernatants and extracted the pellets. Genomic DNA was extracted by a MP

128 Biomedicals FastDNA Spin Kit for soil according to the manufacturer's directions. 
129 Afterwards DNA concentration was analyzed by NanoDrop Spectrophotometer

130 (NanoDrop Technologies, Rockland, DE, USA). The ultrapure water and a MP

131 Biomedicals FastDNA Spin Kit blank served as negative controls to indicate any

132 microbial contamination in the sampling and extraction kit. The V3-V4 hypervariable

133 regions were amplified with the PCR primer pairs $341 \mathrm{f}$ (5'-

134 CCTACGGGNGGCWGCAG) with adaptor $\mathrm{B}$ and $805 \mathrm{r}$ (5'-

135 GACTACHVGGGTATCTAATCC) with adaptor A (Ye et al., 2013; Herlemann et al.,

136 2011), and the barcode nucleotide sequences was equipped between PCR primer and

137 adaptor. The PCR amplification was performed on an ABI GeneAmp ${ }^{\circledR}$ PCR

138 system 9700 (Applied Biosystems, 101 Foster City, CA) using a $20 \mu L-m i x t u r e$

139 containing $4 \mu \mathrm{L} 5 \times$ FastPfu buffer, $2 \mu \mathrm{L} 2.5 \mathrm{mM}$ dNTPs, $0.8 \mu \mathrm{L} 5 \mu \mathrm{M}$ forward primer,

$140 \quad 0.8 \mu \mathrm{L} 5 \mu \mathrm{M}$ reverse primer, $0.4 \mu \mathrm{L}$ Fastfu polymerase, 10 ng template DNA, and 11

$141 \mu \mathrm{L}$ double distilled $\mathrm{H}_{2} \mathrm{O}$. PCR was preformed according to the procedures outlined in

142 the instruction manual of the detection kit: $95^{\circ} \mathrm{C}(3 \mathrm{~min}$, hold $), 95^{\circ} \mathrm{C}(30 \mathrm{~s}), 55^{\circ} \mathrm{C}(30$

$143 \mathrm{~s}), 72^{\circ} \mathrm{C}(42 \mathrm{~s})$, and $10^{\circ} \mathrm{C}$ (hold). The PCR products were separated by $1 \%$ agarose gel

144 electrophoresis and purified with an axygen nucleic acid purification Kit (Axygen,

145 USA). Finally, the purified products were prepared for sequencing on the Illumina

146 MiseqTM plateform (Illumina Inc., San Diego, CA, USA).

\subsection{Sequencing Data}

Raw sequences were processed with the Mothur version 1.25.0

149 (http://www.mothur.org/wiki) and FastX Toolkit software

150 (http://hannonlab.cshl.edu/fastx_toolkit) based on the reference in Ribosomal Database

151 Project (RDP) database for bacteria. All sequences were trimmed by removing the

152 barcodes and low-quality sequences. Total 577523 effective sequences were obtained 
153 for 24 samples and the sequence number of each sample was normalized to 9100 reads

154 (the lowest in the 24 samples) in order to compare the different samples effectively after

155 quality control. The high-quality sequences were clustered into operational taxonomic 156 units (OTUs) at a 97\% sequence similarity cutoff by uCLUST software 157 (http://www.drive5.com/usearch/index.html). The alpha-diversity estimators including

158 Chao1, Coverage, Simpson, and Shannon index were calculated based on the 97\% 159 species similarity. At this similarity level, the variation tendencies across the different 160 samples were shown clearly and in details (Di Bella et al., 2013). The similarity trees 161 were constructed according to the bray-curtis distance coefficient. The Ribosomal 162 Database Project (RDP) was employed to determine the abundance of bacterial taxa at 163 phylum, class, order, family and genus level using similarity cutoff values at $80,85,91$, 16492 and 95\% similarity, respectively (Quadros et al., 2016). MetaPhlAn ((Metagenomic 165 Phylogenetic Analysis) was used to create phylogenetic tree of the bacteria identified 166 from cloud water samples. The nucleotide sequences obtained in this study have been 167 deposited in the Sequence Read Archive (SRA) under accession numbers SRA267745.

168 In order to determine the specific taxa between daytime and nighttime, linear 169 discriminant analysis effect size (LEfSe) was employed in this study 170 (http://huttenhower.sph.harvard.edu/galaxy/). It is able to analyze two or more sets 171 groups at any taxonomic level (Mahnert et al., 2015), and then establishes statistical 172 significance, biological consistency, and effect-size estimation of predicted biomarkers 173 through bacterial taxa explanations. We use the default logarithmic (LDA) value higher 174 than 4 for clarity. 


\section{Result and Discussion}

176

177

178

179

180

181

182

183

184

185

186

\subsection{Bacterial Diversity}

Total 128 to 1910 OTUs were generated from high quality 16S rRNA sequences with an average of 664 OTUs per sample. The saturation rarefaction curves for OTUs approached an asymptote (Figure 1A), indicating the entire diversity was acquired. Notably, the OTUs were higher than that in aerosol collected in the upper troposphere (314; Deleon-Rodriguez et al., 2013), implying that the cloud water at Mt. Tai had a higher bacterial richness. It was also confirmed by Chaol richness index. The value was higher than that in aerosols obtained in $1000 \mathrm{~m}$ over the Noto Peninsula, Japan (410, Maki et al., 2015) and other hurricane-related aerosols at high altitudes across the United States (241, DeLeon-Rodriguez et al., 2013). The Shannon index for estimation of bacterial diversity showed a daily variation tendency. The daytime samples had a higher Shannon index (3.8) than the nighttime samples (3.0), even higher than the Asian dust aerosols (3.51, Jeon et al., 2011). It means that higher richness and diversity of bacteria were observed in cloud water than that in aerosol obtained at high altitude or aerosol collected obtained at the earth ground affected by the Asian-dust events.

Based on the hierarchical clustering analysis, samples containing different OTUs were divergent into two groups (Figure 1B). Eight samples obtained in Sep. 26, Sep. 29 and Oct. 12, 2014 clustered together forming Group I (OTUs: 199, Chao 1: 517.5, and Shannon: 2.0). The remaining samples making up to the largest group II which had a more neutral $\mathrm{pH}(5.8)$ and conduced to a greater bacterial diversity (OTUs: 866, Chao1: 1694.2; Shannon: 4.1). 
About $99.6 \%$ of OTUs were classified into 29 phyla and the most abundant one was

199 Proteobacteria (81.6\%). Similar result was observed in other samples including cloud 200 water (50\%, Vaïtilingom et al., 2012) and aerosol collected at high altitudes (83\%, 201 Bowers et al., 2009; 49.4\%, Bowers et al., 2013; over 50\%, DeLeon-Rodriguez et al., 202 2013). The following phyla were Firmicutes (7.1\%), Bacteroidetes (3.9\%), 203 Actinobacteria (2.3\%), and Cyanobacteria (1.1\%). The abundant of Proteobateria and 204 Bacteroidetes implied a large proportion of gram-negative fractions in total bacteria. 205 While in cultivated bacteria, gram-positive bacterial population were preponderant due 206 to those gram-negative strains lose cultivability after aerosolization (Amato et al., 207 2007b; Heidelberg et al., 1997). Hence the bacteria in cloud water were mainly 208 occupied by the gram-negative bacteria. At the class level, $89.8 \%$ of sequences were 209 classified into 45 taxa, and the Gammaproteobacteria, Betaproteobacteria, 210 Alphaproteobacteria were dominant with relative abundance of $44.5 \%, 23.6 \%$, and 211 12.9\%. Since there were no comparable surveys about cloud microbe using high212 throughput sequencing currently, we compared the results with airborne bacterial 213 community at high altitude sites analyzed by high-throughput sequencing. The 214 community was slightly different with aerosols collected at different altitudes. The 215 marine bacterial members Alphaproteobacteria and Cyanobacteria were dominant in 216 aerosols obtained at $1000 \mathrm{~m}$, while terrestrial bacteria Bacilli and Actinobacteria 217 contributed more sequences to aerosols collected at 3000m (Maki et al., 2015). In 218 present study, Cyanobacteria was not predominant, but it showed a higher abundance $219(2.1 \%)$ in samples B and $\mathrm{H}$ which was related to a back trajectory of air mass come 220 from Yellow Sea than other samples from terrestrial air mass (1.0\%). Bacilli were more 
221 abundant in the Asian dust mineral particles caused by Chinese desert region (49.9\%;

222 Maki et al., 2014) than that obtained in this study (3\%). According to the $24 \mathrm{~h}$ back

223 trajectory prior to sampling, the air mass of Sep 26 (sample G) moved from the Chinese

224 mineral region Shanxi Province (Figure 3). Hence, the abundance of Bacilli in sample

$225 \mathrm{G}$ was 2.2 times higher than that in non-mineral-influenced samples. It is coincident

226 with the result reported by Maki (2015) that members of Bacilli at high altitudes have

227 potential to form resistant endospores and take part in long distance transmission.

228 At the order level, Pseudomonadales (Gammaproteobacteria), which is commonly 229 found in the leaf-surface environment (Bowers et al., 2012), was most abundant (over $23030 \%$ ) in cloud water, may be resulting from approximately $80 \%$ vegetation coverage at 231 Mt. Tai (Figure 2). Further, 192 families were identified in cloud samples and the taxa 232 of dominant families were similar to those groups identified in other airborne studies 233 (Bowers et al., 2012 and Maki et al., 2014). However the abundance was significantly 234 different. Moraxellaceae family affiliating to Pseudomonadales was considered to be 235 the most abundant family at Mt. Tai (35.4\%). This value was much higher than that 236 obtained at the summit of Mt. Werner $\left(40^{\circ} 27^{\prime} \mathrm{N}, 106^{\circ} 43^{\prime} \mathrm{W}, 3220 \mathrm{~m}\right.$ a.s.l), USA (less 237 than 10\%; Bowers et al., 2012). This bacterium is also an important part of bacterial 238 community in other cold environments such as Antarctic soil (Bowman et al., 1996), 239 Antarctic sea ice (Bozal et al., 2003), and snow (Amato et al., 2007b). At the genus 240 level, members of Gamma-Proteobacteria have been proved to participate in the 241 nucleation process by act as cloud condensation nuclei (CCN) and ice nuclei (IN). 242 Through the high throughput sequencing, we observed sequences with homology to the 243 following known cloud condensation nucleating and ice nucleating bacteria: 244 Sphingomonas (6.7\%), Pseudomonas (4.1\%), Bacillus (1.1\%), Rhodococcus (0.5\%), 
and Psychrobacter (0.4\%). These bacteria cycling in near-surface atmosphere

246 experience aerosolization processes by emission from surface cover (soil, ocean, and

247 vegetation) and deposition processes by rain and cloud. First, bacteria take part in the 248 cloud formation via offering a surface for the water vapor condensation at the 249 supersaturation over the particle surface. The presence of lipopolysaccharides or 250 exopolymeric substances on bacterial surface can enhance its activity ability to cloud 251 droplets (Delort et al., 2010). For instance, several bacteria (such as Pseudomonas 252 strains) can produce biosurfactants which may decrease the surface tension of cloud 253 droplets and result in the supersaturation (Ahern et al., 2007). The pioneering works 254 have found strains belonging to gram-negative bacterium Pseudomonas and gram255 positive bacteria (Rhodococcus and Bacillus) are biosurfactant producers and play a 256 role in cloud condensation nuclei formation (Maki et al., 1974; Hirano et al., 2000; 257 Bauer et al., 2003; Santl-Temkiv et al., 2015). Secondly, the ice-nuclei-active bacteria 258 in cloud water have strong ice nucleation efficiency between -7 and $-9^{\circ} \mathrm{C}$, especially 259 epiphytic bacteria (Ponder et al., 2005, Delort et al., 2010).

\subsection{Differences between Daytime and Nighttime.}

261 Across different sampling time (daytime and nighttime), bacterial community 262 structure exhibited obvious disparities as shown in Figure 4. Total 31 taxa were clearly 263 distinguishable using the default logarithmic (LDA) value higher than 2. Total 14 taxa 264 enriched in daytime, while no fine lineages had an LDA value higher than 4. At 265 daytime, the active bacteria not only participate in the atmospheric biological process 266 (biotransformation and biochemical degradation pathways), but also have the ability to 267 absorb or reflect the sunlight, which may induce photochemistry reaction (Delort et al., 268 2010; Despres et al., 2012). Photochemistry reaction was limited during nighttime. And 
269 low temperature may cause the shift of bacterial community. During nighttime five 270 major indicators affiliated to the phylum of Proteobacteria enriched including 271 Alphaproteobacteria (class) and the cluster of Sphingomonadales (from class to 272 species). Vaitilingom et al. (2010) found that biodegradation by Sphingmonas strains 273 at nighttime contribute more to cloud chemistry than that during the daytime due to the 274 competition with photochemistry during the daytime. Amato et al. (2005) also proved 275 that Spingmonas was psychrophilic and able to grow better at low temperature $\left(5^{\circ} \mathrm{C}\right)$ 276 due to that they synthesis yellow or off-white color pigment colonies likely belonging 277 to the carotenoid family which has been described to protect bacteria from low 278 temperatures (Vincent et al., 2000; Asker et al., 2007). Thus, the Sphingmonas under 279 the conditions of no light and low temperature may enriched during nighttime

\subsection{Interrelationship between Bacterial Community and Environmental factors}

281 The categorization classified by the hierarchical clustering analysis in the bacterial 282 community structures could be identified at the order level. Pseudomonadales 283 contributed almost $39.2 \%$ of the bacteria in group II. While in group I, this order 284 reduced to less than $17.8 \%$ and replaced by members of the Burkholderiales $(35.7 \%)$ 285 and Enterobacteriales (28.7\%) apparently which as an effect of marine especially in 286 sample B. Previous researchers have presented the discrepancies of bacterial 287 community across different samples. Bowers et al., (2011) reported that the shifts of 288 the airborne bacterial community in three land-use types, in part, driven by the 289 differences in the relative contributions of bacteria from specific source habitats. Jeon 290 et al., (2011) observed that the Asian dust directly affect the airborne bacterial 291 communities by air mass transport pathways. Maki et al., (2015) proved the effect of 292 air mass and metrological conditions on the bacterial community at different altitudes 
293 in downwind atmosphere. Amato et al. (2007c) reported that bacteria emitted by ocean 294 could transmit into cloud droplets in the free troposphere. Here the abundance of marine 295 bacterium Pseudomonas (Lee et al., 1977) in marine-influenced samples was found to 296 be 9-times higher than the non-marine influenced cloud samples. Owing to the lack of 297 standardization in the sample collection and analysis process, it is hard to explain these 298 differences with previous publications. The discrepancies may be due to the different 299 analysis methods (Denaturing Gradient Gel Electrophoresis, cultured method, and 300 BLASTN application, and high throughput sequencing), sampling methods, 301 metrological conditions (temperature, UV radiation, wind speed, and humidity), 302 sampling location (geographic location, land use, traffic nearby, and altitude), and 303 environmental factor ( $\mathrm{pH}$, conductivity, $\mathrm{PM}_{2.5}, \mathrm{SO}_{2}, \mathrm{O}_{3}, \mathrm{CO}, \mathrm{NO}_{2}$, and temperature).

304 Herein the redundancy discriminant analysis showed that the environmental factors 305 distinctly related to the variations of species-environment relation in different samples. 306 The first axis explained $66.7 \%$ of the variation of species-environment relationship, and 307 the second axes explained $14.0 \%$ (Figure 5). The RDA with original data shows that $\mathrm{O}_{3}$ 308 and $\mathrm{SO}_{2}$, which made 0.001 $\mathrm{Pr}$ and 0.019 Pr with 999 permutations number based on $3091 \%$ level in a permutation test, was the critical factors for the species-environment 310 relationship. Corresponding values were higher than 0.05 for other environmental 311 factors. Therefore, $\mathrm{O}_{3}$ and $\mathrm{SO}_{2}$ in atmosphere contributed statistically significant to 312 variation of bacterial community. The $\mathrm{O}_{3}$ and $\mathrm{SO}_{2}$ gases participated in the disinfection 313 of bacteria and formation of $\mathrm{SO}_{4}{ }^{2-}$ in cloud water. Zuma et al. (2009 and 2010) showed 314 that ozone have bigger germicidal effectiveness to gram-negative and gram-positive 315 strains than the free radicals. Kim et al., (2000) observed a lower survivors fraction of 316 Pseudomonas strains with increasing ozone treatment. $\mathrm{H}_{2} \mathrm{SO}_{4}$ generated by $\mathrm{SO}_{2}$ in 
atmosphere were known to be toxic for micrograms such as Rhodobacteraceae and

318 Desulfobacterales (Gao et al., 2016; Won et al., 1969). In the present study, these two

319 factors mainly have a positive influence on the relative abundance of Noviherbasirllum,

320 Serratia, and Massilia, and then act on the distribution of samples dominated by these

321 genera, such as sample A, B, and C in group I. In addition, $\mathrm{PM}_{2.5}$, conductivity, and

322 temperature were also important to positive correlation with the relative abundance of

323 Sphingomonas, which may be explained by their relatively tolerance of high PM

324 pollutants and capability to degrade the organic matter in atmosphere (Gingell et al.,

325 1976; Ye et al., 1995). It was consistent with Sun et al. (2014) that temperature was a

326 key factor in the aquatic bacterial community's composition. While in group II, $\mathrm{pH}$ and

$327 \mathrm{NO}_{2}$ have also great impact on the Acinetobacter and Acidovorax. Further

328 investigations combination culture techniques and bacterial concentration analysis are

329 required to accurately evaluate the detail influencing mechanisms on the growth and

330 development of bacteria.

331 4. Conclusion

332 In order to describe the bacterial community in atmospheric cloud system and its

333 variation, cloud water were collected at the summit of Mt. Tai and analyzed by high

334 throughput sequencing. Diverse bacterial population at high altitude was dominated by

335 gram-negative fractions, e.g. Acinetobacter, Serratia, Massilia, Sphingomonas,

336 Acidovorax, and Pseudomonas. Some member of these taxa are able to participate in

337 the nucleation process by act as cloud condensation nuclei (CCN) and ice nuclei (IN)

338 in cloud system. The bacterial community showed a significant daily tendency between

339 daytime and nighttime. Meanwhile environmental factors including $\mathrm{O}_{3}$, and $\mathrm{SO}_{2}$

340 critically contributed to the variation of bacterial community structure. In the future the 
341 real time quantitative PCR and cultured experiments should be combined to target the

342 detail impact mechanisms of environmental factors on the variation of bacteria 343 community.

\section{Conflict of Interest}

345 The authors declare no conflict of interest.

\section{Acknowledgement}

347 This work was supported by the National Natural Science Foundation of China (No.

348 41375126, 41605113, 21190053, 21527814), Taishan Scholar Grant (grant number 349 ts20120552), Cyrus Tang Foundation (No. CTF-FD2014001), the Ministry of Science 350 and Technology of China (No. SQ2016ZY01002231, 2014BAC22B01) and Marie 351 Skłodowska-Curie Actions (H2020-MSCA-RISE-2015-690958).

\section{References}

353 Ahern HE, Walsh KA, Hill TCJ, Moffett BF. Fluorescent pseudomonads isolated from 354 Hebridean cloud and rain water produce biosurfactants but do not cause ice 355 nucleation. Biogeosciences 2007; 4: 115-124.

356 Amato P, Demeer F, Melaouhi A, Fontanella S, Martinbiesse AS, Sancelme M, Laj P, 357 Delort AM. A fate for organic acids, formaldehyde and methanol in cloud water: 358 their biotransformation by microorganisms. Atmos Chem Phys 2007a; 7: 4159-4169.

359 Amato P, Parazols M, Sancelme M, Laj P, Mailhot G, Delort AM. Microorganisms 360 isolated from the water phase of tropospheric clouds at the Puy de Dome: major 
361 groups and growth abilities at low temperatures. Fems Microbiol Ecol 2007b; 59: $362 \quad 242-254$.

363 Amato P, Ménager M, Sancelme M, Laj P, Mailhot G, Delort AM. Microbial population 364 in cloud water at the Puy de Dôme: Implications for the chemistry of clouds. Atmos $365 \quad$ Environ 2005; 39: 4143-4153.

366 Amato P, Parazols M, Sancelme M, Mailhot G, Laj P, Delort AM. An important oceanic 367 source of micro-organisms for cloud water at the Puy de Dôme (France). Atmos $368 \quad$ Environ 2007c; 41: 8253-8263.

369 Amato P, Joly M, Schaupp C, Attard E, Möhler O, Morris CE, Brunet Y, Delort AM. 370 Survival and ice nucleation activity of bacteria as aerosols in a cloud simulation 371 chamber. Atmos Chem Phys 2015; 15: 4055-4082.

372 Asker D, Beppu T, Ueda K. Sphingomonas jaspsi sp. nov., a novel carotenoid373 producing bacterium isolated from Misasa, Tottori, Japan. Int J Syst Evol Micr 2007; $374 \quad 57: 1435-1441$.

375 Bauer H, Giebl H, Hitzenberger R, Kasper-Giebl A, Reischl G, Zibuschka F, Puxbaum 376 H. Airborne bacteria as cloud condensation nuclei. J Geophys Res 2003; 108: 1919$377 \quad 1964$.

378 Birgit S, Hans P, Rol P. Bacterial growth in supercooled cloud droplets. Geophys Res 379 Lett 2001; 28: 239-242.

380 Bowman JP, Cavanagh J, Austin, J.J., Sanderson, K. Novel Psychrobacter species from 381 antarctic ornithogenic soils. Int J Syst Bacteriol 1996; 46: 841-848. 
382 Bowers RM, Lauber CL, Wiedinmyer C, Hamady M, Hallar AG, Fall R, Knight R,

383 Fierer N. Characterization of airborne microbial communities at a high-elevation site

384 and their potential to act as atmospheric ice nuclei. Appl Environ Microbiol 2009;

$385 \quad 75: 5121-5130$.

386 Bowers R M, Mcletchie S, Knight R, Fierer N. Spatial variability in airborne bacterial 387 communities across land-use types and their relationship to the bacterial 388 communities of potential source environments. ISME J 2010; 5: 601-612.

389 Bowers RM, McCubbin IB, Hallar AG, Fierer N. Seasonal variability in airborne 390 bacterial communities at a high-elevation site. Atmos Environ 2012; 50: 41-49.

391 Bowers RM, Clements N, Emerson JB, Wiedinmyer C, Hannigan MP, Fierer N. 392 Seasonal variability in bacterial and fungal diversity of the near-surface atmosphere. $393 \quad$ Environ Sci Technol 2013; 47: 12097-12106.

394 Bozal N, Montes MJ, Tudela E, Guinea J. Characterization of several Psychrobacter 395 strains isolated from Antarctic environments and description of Psychrobacter luti 396 sp. nov. and Psychrobacter fozii sp. nov. Int J Syst Evol Microbiol 2003; 53: 1093$397 \quad 1100$.

398 Cao C, Jiang W, Wang BY, Fang JH, Lang JD, Tian G, Jiang JK, Zhu TF. Inhalable 399 Microorganisms in Beijing's PM2.5 and PM10 Pollutants during a Severe Smog Event. $400 \quad$ Environ Sci Tech 2014; 48: 1499-1507.

401 Collett JL, Sherman DE, Moore KF, Hannigan MP, Lee T. Aerosol Particle Processing 402 and Removal by Fogs: Observations in chemically heterogeneous central california 403 radiation fogs. Water Air Soil Poll Focus 2001; 1: 303-312. 
404 DeLeon-Rodriguez N, Lathem TL, Rodriguez-R LM, Barazesh JM, Anderson BE, 405 Beyersdorf AJ, Ziemba LD, Bergin M, Nenes A, and Konstantinidis KT. 406 Microbiome of the upper troposphere: Species composition and prevalence, effects 407 of tropical storms, and atmospheric implications. Proc Natl Acade Sci USA 2013; $408 \quad 110: 2575-2580$.

409 Delort AM, Vaïtilingom M, Amato P, Sancelme M, Parazols M, Mailhot G, Laj P, 410 Deguillaume L. A short overview of the microbial population in clouds: Potential 411 roles in atmospheric chemistry and nucleation processes. Atmos Res 2010; 98: 249412260.

413 Despres VR, Huffman JA, Burrows SM, Hoose C, Safatov AS, Buryak G, Frohlich414 Nowoisky J, Elbert W, Andreae MO, Poschl U, Jaenicke R. Primary biological 415 aerosol particles in the atmosphere: a review. Tellus B 2012; 4: 1-58.

416 Di Bella JM, Bao Y, Gloor GB, Burton JP, Reid G. High throughput sequencing 417 methods and analysis for microbiome research. J Microbiol Meth 2013; 95: 401-414.

418 Ervens B. Modeling the processing of aerosol and trace gases in clouds and fogs. Chem $419 \quad$ Rev 2015; 115: 4157-4198.

420 Gao M, Yan X, Qiu T, Han M, Wang X. Variation of correlations between factors and 421 culturable airborne bacteria and fungi. Atmos Environ 2016; 128: 10-19.

422 Gingell SM, Campbell R, Martin MH. The effect of zinc, lead and cadmium pollution 423 on the leaf surface microflora. Environ Pollut 1976; 11: 25-37.

424 Guo J, Wang Y, Shen XH, Wang Z, Lee T, Wang XF, Li PH, Sun MH, Collett JL, 425 Wang WX. Characterization of cloud water chemistry at Mount Tai, China: seasonal 
426 variation, anthropogenic impact, and cloud processing. Atmos Environ 2012; 60: $427 \quad 467-476$.

428 Heidelberg JF, Shahamat M, Levin M, Rahman I, Stelma G, Grim C, Colwell RR. 429 Effect of aerosolization on culturability and viability of Gram-negative bacteria. $430 \quad$ Appl Environ Microbiol 1997; 63: 3585-3588.

431 Herlemann DP, Labrenz M, Jurgens K, Bertilsson S, Waniek JJ, Andersson AF. 432 Transitions in bacterial communities along the $2000 \mathrm{~km}$ salinity gradient of the Baltic $433 \quad$ Sea. ISME J 2011; 5: 1571-1579.

434 Hill KA, Shepson PB, Galbavy ES, Anastasio C, Kourtev PS, Konopka A, Stirm BH. 435 Processing of atmospheric nitrogen by clouds above a forest environment. J Geophys $436 \quad$ Res 2007; 112: 1-16.

437 Hirano SS, Upper CD. Bacteria in the leaf ecosystem with emphasis on Pseudomonas 438 syringae-a pathogen, ice nucleus, and epiphyte. Microbiol Mol Biol 2000; 64: 624439653.

440 Jeon EM, Kim HJ, Jung K, Kim JH, Kim MY, Kim YP, Ka JO. Impact of Asian dust 441 events on airborne bacterial community assessed by molecular analyses. Atmos $442 \quad$ Environ 2011; 45: 4313-4321.

443 Joly M, Attard E, Sancelme M, Laurent D, Caroline G, Cindy EM, Pierre A, Anne444 Marie D. Ice nucleation activity of bacteria isolated from cloud water. Atmos $445 \quad$ Environ 2013; 70: 392-400.

446 Kim JG, Yousef AE. Inactivation kinetics of foodborne spoilage and pathogenic 447 bacteria by ozone. J Food Sci 2000; 65: 521-528. 
448 Kourtev PS, Hill KA, Shepson PB, Konopka A. Atmospheric cloud water contains a 449 diverse bacterial community. Atmos Environ 2011; 45: 5399-5405.

450 Lee JV, Gibson DM, Shewan JM. A numerical taxonomic study of some Pseudomonas$451 \quad$ like marine bacteria. J Gen Microbiol 1977; 9: 439-451.

452 Li PF, Li X, Yang CY, Wang XJ, Chen JM, Collett JL. Fog water chemistry in 453 Shanghai. Atmos Environ 2011a; 45: 4034-4041.

454 Li WJ, Wang Y, Collett JL, Chen JM, Zhang XY, Wang ZF, Wang WX. Microscopic 455 evaluation of trace metals in cloud droplets in an acid precipitation region. Environ $456 \quad$ Sci Technol 2013; 47: 460-470.

457 Li WJ, Shao LY, Zhang DZ, Ro C, Hu M, Bi XH, Geng H, Matsuki A, Niu HY, Chen 458 JM. A review of single aerosol particle studies in the atmosphere of East Asia: 459 morphology, mixing state, source, and heterogeneous reactions. J Clean Prod 2016; $460 \quad 112: 1330-1349$.

461 Li X, Li PF, Yan LL, Chen JM, Cheng TT, Xu SF. Characterization of polycyclic 462 aromatic hydrocarbons in fog-rain events. J Environ Monitor 2011b; 13: 2988-2993.

463 Liu XH, Wai KM, Wang Y, Zhou J, Li PH, Guo J, Xu PJ, Wang WX. Evaluation of 464 trace elements contamination in cloud/fog water at an elevated mountain site in $465 \quad$ Northern China. Chemosphere 2012; 88: 531-541.

466 Mahnert A, Moissi-Eichinger C, Berg G. Microbiome interplay: plants alter microbial 467 abundance and diversity within the built environment. Front Microbiol 2015; 6: 887, 468 doi: $10.3389 /$ fmicb.2015.00887. 
Maki LR, Galyan EL, Chang-Chien MM, Caldwell DR. Ice nucleation induced by

470 pseudomonas syringae. Appl Microbiol 1974; 28: 456-459.

471 Maki T, Puspitasari F, Hara K, Yamada M, Kobayashi F, Hasegawa H, Iwasaka Y.

472 Variations in the structure of airborne bacterial communities in a downwind area 473 during an Asian dust (Kosa) event. Sci Total Environ 2014; 488-489: 75-84.

474 Maki T, Hara K, Kobayashi F, Kurosaki Y, Kakikawa M, Matsuki A, Bin C, Shi G, 475 Hasegawa H, and Iwasaka Y. Vertical distribution of airborne bacterial communities 476 in an Asian-dust downwind area, Noto Peninsula. Atmos Environ 2015; 119: 282477293.

478 Marinoni A, Laj P, Sellegri K, Mailhot G. Cloud chemistry at the Puy de Dôme: 479 variability and relationships with environmental factors. Atmos Chem Phys 2004; 4: $480 \quad 715-728$.

481 Martinsson BG, Frank G, Cederfelt SI, Swietlicki E, Berg OH, Zhou JC, Bower KN, 482 Bradbury C, Birmili W, Stratmann F. Droplet nucleation and growth in orographic 483 clouds in relation to the aerosol population. Atmos Res 1999; 50: 289-315.

484 Matthias-Maser S, Bogs B, Jaenicke R, The size distribution of primary biological 485 aerosol particles in cloud water on the mountain Kleiner Feldberg/Taunus (FRG). $486 \quad$ Atmos Res 2000; 54: 1-13.

487 Modini RL, Frossard AA, Ahlm L, Russell LM, Corrigan CE, Roberts GC, Hawkins 488 LN, Schroder JC, Bertram AK, Zhao R, Lee AKY, Abbatt JPD, Lin J, Nenes A, 489 Wang Z, Wonaschutz A, Sorooshian A, Noone KJ, Jonsson H, Seinfeld JH, Toom- 
491 off the coast of California. J Geophys Res 2015; 120: 4282-4303.

492 Ponder MA, Gilmour SJ, Bergholz PW, Mindock CA, Hollingsworth R, Thomashow

493 MF. Characterization of potential stress responses in ancient Siberian permafrost 494 psychroactive bacteria. FEMS Microbiol Ecol 2005; 53: 103-115.

495 Quadros PDD, Zhalnina K, Davis-Richardson AG, Drew JC, Menezes FB, Camargo 496 FAD, Triplett EW. Coal mining practices reduce the microbial biomass, richness and 497 diversity of soil. Appl Soil Ecol 2016; 98: 195-203.

498 Šantl-Temkiv T, Sahyoun M, Kai F, Hartmann S, Augustin-Bauditz S, Stratmann F, 499 Wex H, Clauss T, Nielsen NW, Sørensen JH. Characterization of airborne ice$500 \quad$ nucleation-active bacteria and bacterial fragments. Atmos Environ 2015; 109: 105$501 \quad 117$.

502 Smets W, Moretti S, Denys S, Labeer S. Airborne bacteria in the atmosphere: Presence, 503 purpose, and potential. Atmos Environ 2016; 139: 214-221.

504 Sun Z, Li G, Wang C, Jing Y, Zhu Y, Zhang S, Liu Y. Community dynamics of 505 prokaryotic and eukaryotic microbes in an estuary reservoir. Sci Rep-UK 2014; 4: $506 \quad 6966$.

507 Vaitilingom M, Amato P, Sancelme M, Laj P, Leriche M, Delort AM. Contribution of 508 microbial activity to carbon chemistry in clouds. Appl Environ Microbiol 2010; 76: $509 \quad 23-29$. 
510 Vaïtilingom M, Attard E, Gaiani N, Sancelme M, Deguillaume L, Flossmann AI, 511 Amato P, Delort AM. Long-term features of cloud microbiology at the puy de Dôme 512 (France). Atmos Environ 2012; 56: 88-100.

513 Vincent WF, Gibson JAE, Pienitz R, Villeneuve V. Ice shelf microbial ecosystems in 514 the high Arctic and implications for life on snowball earth. Sci Nat 2000; 87: 137515141.

516 Wang XF, Chen JM, Sun JF, Li WJ, Yang LX, Wen L, Wang WX, Wang XM, Collett 517 Jr JL, Shi Y, Zhang QZ, Hu QT, Yao L, Zhu YH, Sui X, Sun XM, Mellouki A. Severe 518 haze episodes and seriously polluted fog water in Ji'nan, China. Sci Total Environ $519 \quad 2014 ; 493: 133-137$.

520 Wang Y, Guo J, Wang T, Ding AJ, Gao J, Zhou Y, Collett JL, Wang WX. Influence of 521 regional pollution and sandstorms on the chemical composition of cloud/fog at the 522 summit of Mt. Taishan in northern China. Atmos Res 2011; 99: 434-442.

523 Won WD, Ross H. Reaction of airborne Rhizobium meliloti to some environmental 524 factors. Appl Microbiol 1969; 18: 555-557.

525 Ye DY, Siddiqi MA, Maccubbin AE, Kumar S, Sikka HC. Degradation of polynuclear 526 aromatic hydrocarbons by Sphingomonas paucimobilis. Environ Sci Technol 1995; $527 \quad 30: 136-142$.

528 Ye Y, Carlsson G, Agholme MB, Wilson JAL, Roos A, Henriques-Normark B, 529 Engstrand L, Modéer T, Pütsep K. Oral bacterial community dynamics in paediatric 530 patients with malignancies in relation to chemotherapy-related oral mucositis: a $531 \quad$ prospective study. Clin Microbiol Infec 2013; 19: 559-567. 
532 Zuma FN, Jonnalagadda, SB. Studies on the O3-initiated disinfection from Gram533 positive bacteria Bacillus subtilis in aquatic systems. J Environ Sci Heal A 2010; 45: $534 \quad 224-232$.

535 Zuma FN, Lin J, Jonnalagadda SB. Kinetics of inactivation of Pseudomonas aeruginosa 536 in aqueous solutions by ozone aeration. J Environ Sci Heal A 2009; 44: 929-935. 
537 Table 1 Sampling time and environmental parameters over the sampling period.

\begin{tabular}{|c|c|c|c|c|c|c|c|c|}
\hline Sample ID & Sampling Time & $\overline{\mathrm{pH}}$ & $\mathrm{PM}_{2.5}\left(\mu \mathrm{g} \mathrm{m}^{-3}\right)$ & Conductivity & $\mathrm{CO}(\mathrm{ppm})$ & $\mathrm{SO}_{2}(\mathrm{ppb})$ & $\mathrm{O}_{3}(\mathrm{ppb})$ & $\mathrm{NO}_{2}(\mathrm{ppb})$ \\
\hline$\overline{\mathrm{A} 1}$ & 09/26/2014 0:00-2:00 & 5.8 & 32.9 & 813.5 & 1.0 & 0.9 & 72.1 & \\
\hline A2 & 09/26/2014 2:00-3:00 & 6.3 & 12.9 & 365.7 & 0.7 & 0.6 & 66.4 & \\
\hline B1 & 09/29/2014 0:00-3:00 & 6.9 & 0.9 & 50.5 & 0.4 & 0.1 & 55.9 & \\
\hline $\mathrm{B} 2$ & 09/29/2014 3:00-5:00 & 6.6 & 0.7 & 66.0 & 0.5 & 0.2 & 44.7 & \\
\hline B3 & 09/29/2014 5:00-7:00 & 6.7 & 2.0 & 44.9 & 0.4 & 0.1 & 46.6 & \\
\hline $\mathrm{C} 1$ & 10/12/2014 8:30-10:00 & 3.8 & 28.0 & 330.8 & 1.2 & 4.2 & 51.1 & 8.7 \\
\hline $\mathrm{C} 2$ & 10/12/2014 10:00-11:00 & 4.2 & 16.3 & 236.8 & 1.0 & 1.6 & 43.0 & 6.8 \\
\hline $\mathrm{C} 3$ & 10/12/2014 11:00-12:00 & 5.4 & 3.9 & 71.7 & 0.7 & 0.8 & 26.6 & 7.5 \\
\hline D1 & 10/19/2014 10:43-13:23 & 6.6 & 3.8 & 141.7 & 0.6 & 0.5 & 8.9 & 4.9 \\
\hline $\mathrm{D} 2$ & $10 / 19 / 2014$ 13:23-15:02 & 6.1 & 4.4 & 109.7 & 0.6 & 0.4 & 6.5 & 5.3 \\
\hline E1 & 10/20/2014 16:55-18:15 & 5.1 & 10.6 & 236.8 & 1.6 & 1.1 & 11.9 & 9.0 \\
\hline E2 & 10/20/2014 18:15-19:35 & 4.9 & 23.4 & 295.2 & 1.5 & 0.6 & 11.9 & 6.0 \\
\hline F1 & 10/21/2014 0:10-2:20 & 4.3 & 2.6 & 154.7 & 0.8 & 0.4 & 10.3 & 3.1 \\
\hline
\end{tabular}




\begin{tabular}{ccccccccc} 
F2 & $10 / 21 / 20142: 00-4: 55$ & 5.1 & 1.5 & 42.2 & 0.7 & 0.3 & 12.5 & 3.5 \\
G1 & $10 / 23 / 201420: 15-23: 30$ & 5.8 & 12.5 & 370.7 & & 0.3 & 7.7 & 13.7 \\
G2 & $10 / 23 / 201423: 30-3: 30$ & 5.7 & 13.2 & 354.9 & & 0.2 & 3.5 & 13.1 \\
H1 & $10 / 29 / 201419: 40-1: 30$ & 6.4 & 26.0 & 352.6 & 1.2 & 0.4 & 8.3 & 6.0 \\
J1 & $10 / 30 / 20141: 30-4: 00$ & 6.2 & 4.0 & 60.4 & 0.7 & 0.2 & 8.4 & 6.4 \\
J2 & $10 / 30 / 201412: 00-14: 00$ & 6.6 & 2.3 & 20.4 & 0.4 & 0.1 & 5.5 & 6.6 \\
J3 & $10 / 30 / 201414: 00-16: 00$ & 6.2 & 1.4 & 13.4 & 0.4 & 0.1 & 9.5 & 5.6 \\
J4 & $10 / 30 / 201416: 00-17: 30$ & 6.2 & 2.4 & 22.0 & 0.4 & 0.1 & 12.1 & 5.9 \\
J5 & $10 / 30 / 201417: 30-19: 00$ & 6.3 & 4.9 & 22.3 & 0.6 & 0.1 & 12.5 & 6.7 \\
J6 & $10 / 30 / 201419: 00-20: 30$ & 6.9 & 2.3 & 184.7 & 0.6 & 0.1 & 12.4 & 6.0 \\
K1 & $10 / 31 / 201415: 55-17: 00$ & 4.4 & 4.8 & 128.1 & 0.8 & 0.3 & 3.2 & 10.5 \\
\hline
\end{tabular}




\section{List of Figures}

Figure 1. The saturation rarefaction curves (A) and hierarchical clustering (B) of the abundant communities at OTU level of 24 cloud water samples..

Figure 2. Bacterial community structure of cloud water identified at the order level. Only bacteria with relative abundance $\geqslant 1 \%$ were labeled.

Figure 3. Geographical location of Mt. Tai and HYSPILT back trajectories of air masses during sampling period. The $24 \mathrm{~h}$ backward trajectories were obtained from the NOAA ARL (http://ready.arl.noaa.gov/).

Figure 4. Indicator microbial groups within the two types of cloud water with LDA values higher than 2 (red indicating daytime and green indicating nighttime).

Figure 5. Redundancy discriminant analysis (RDA) biplot of the distribution of bacterial communities with environmental variables in cloud water at Mt. Tai. The upper left legend shows color-coding indicating ten cloud events. 

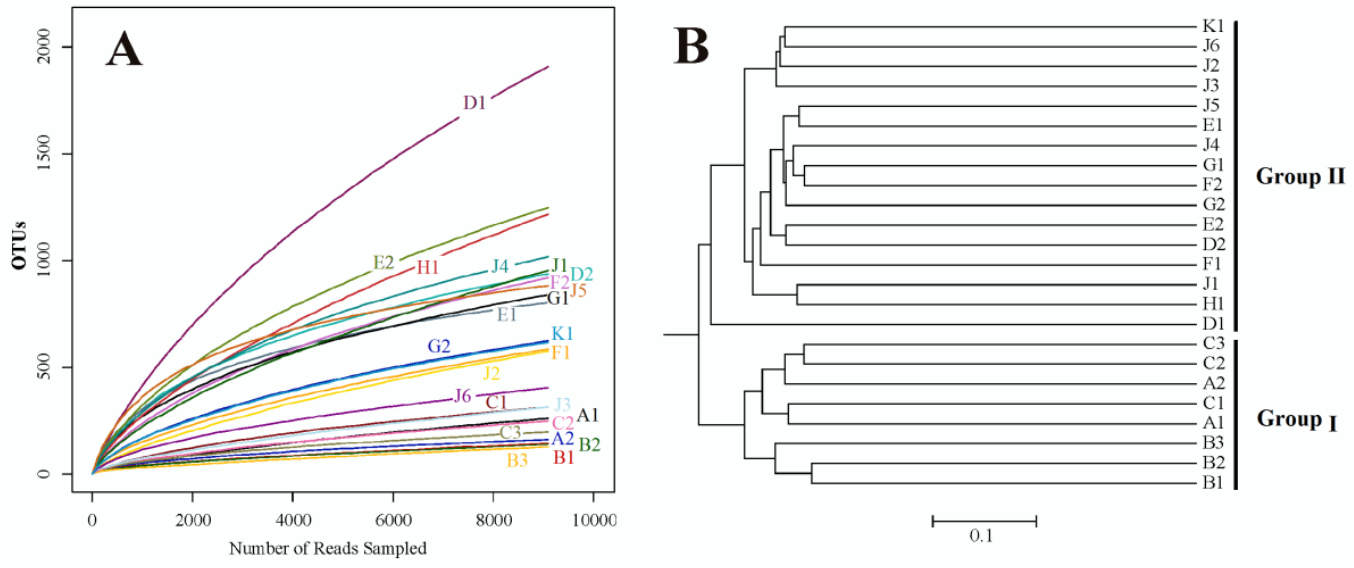

Figure 1 


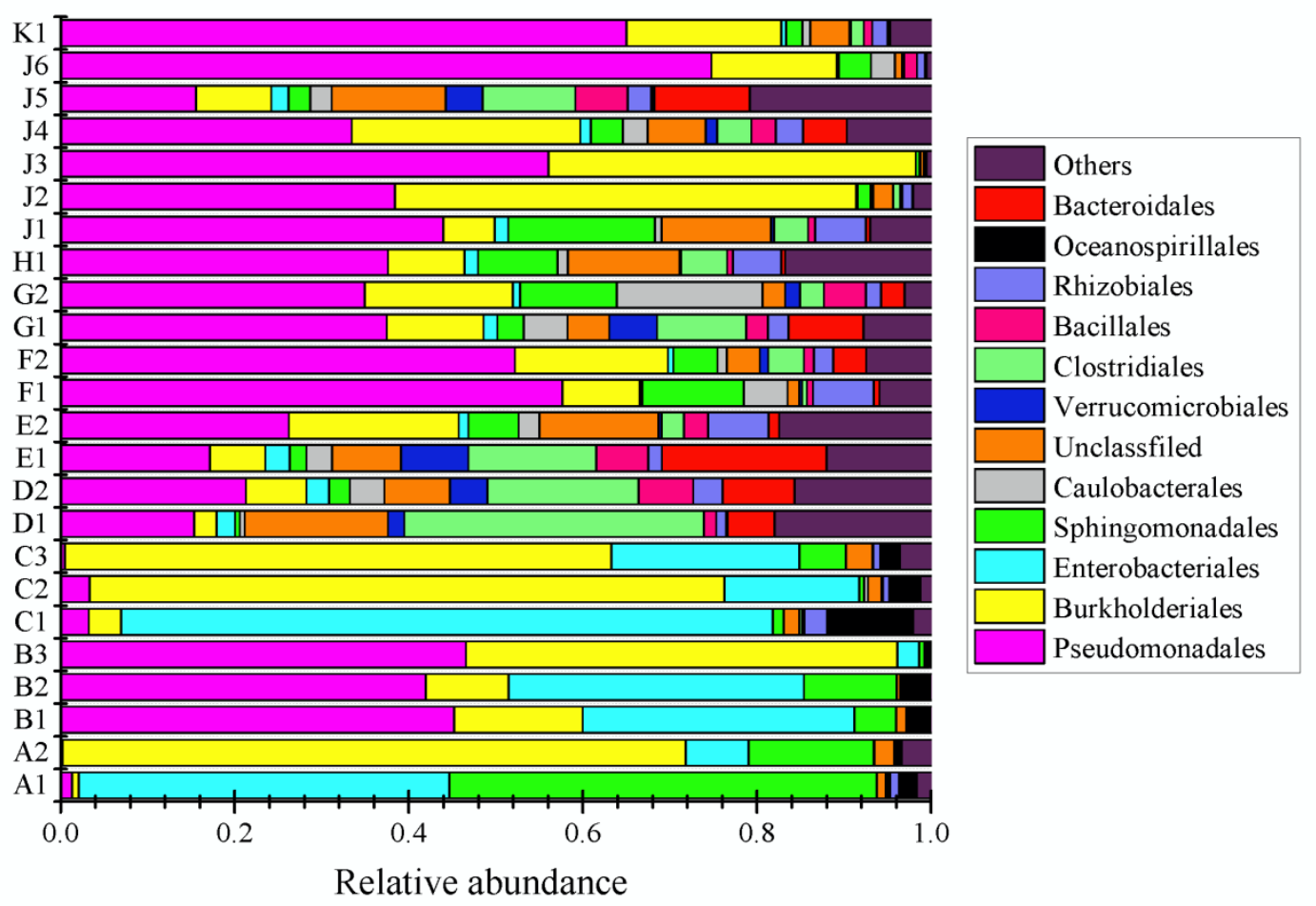

Figure 2 


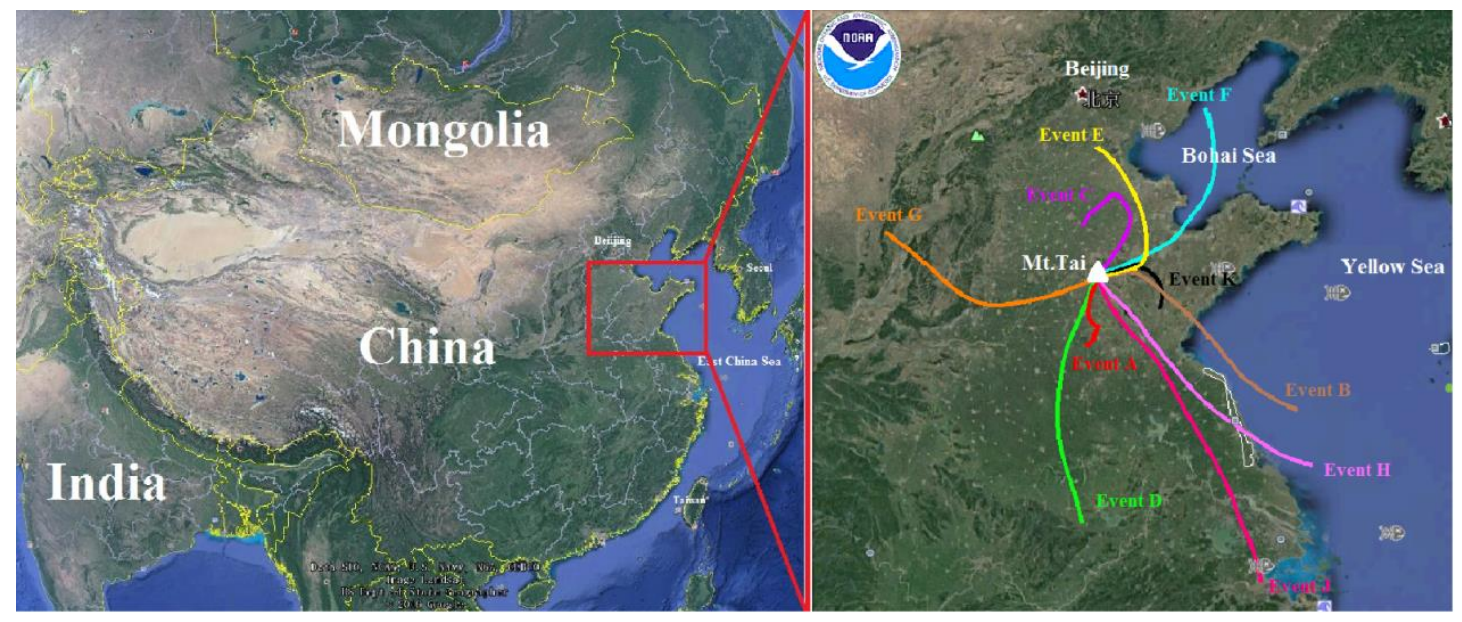

Figure 3 


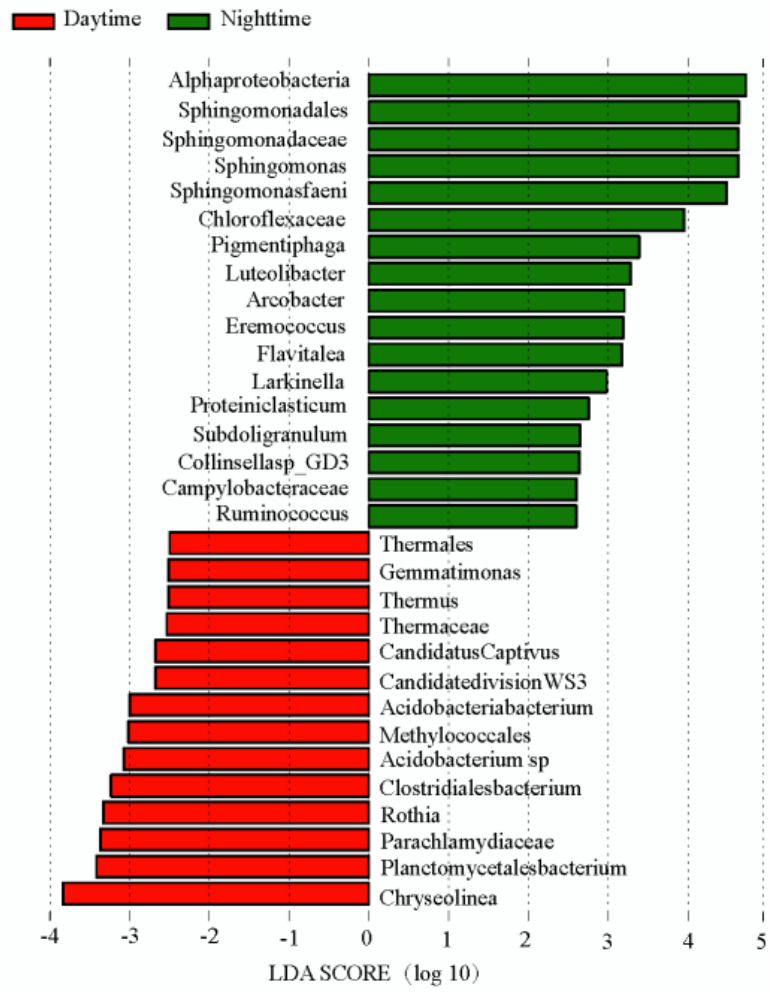

Figure 4 


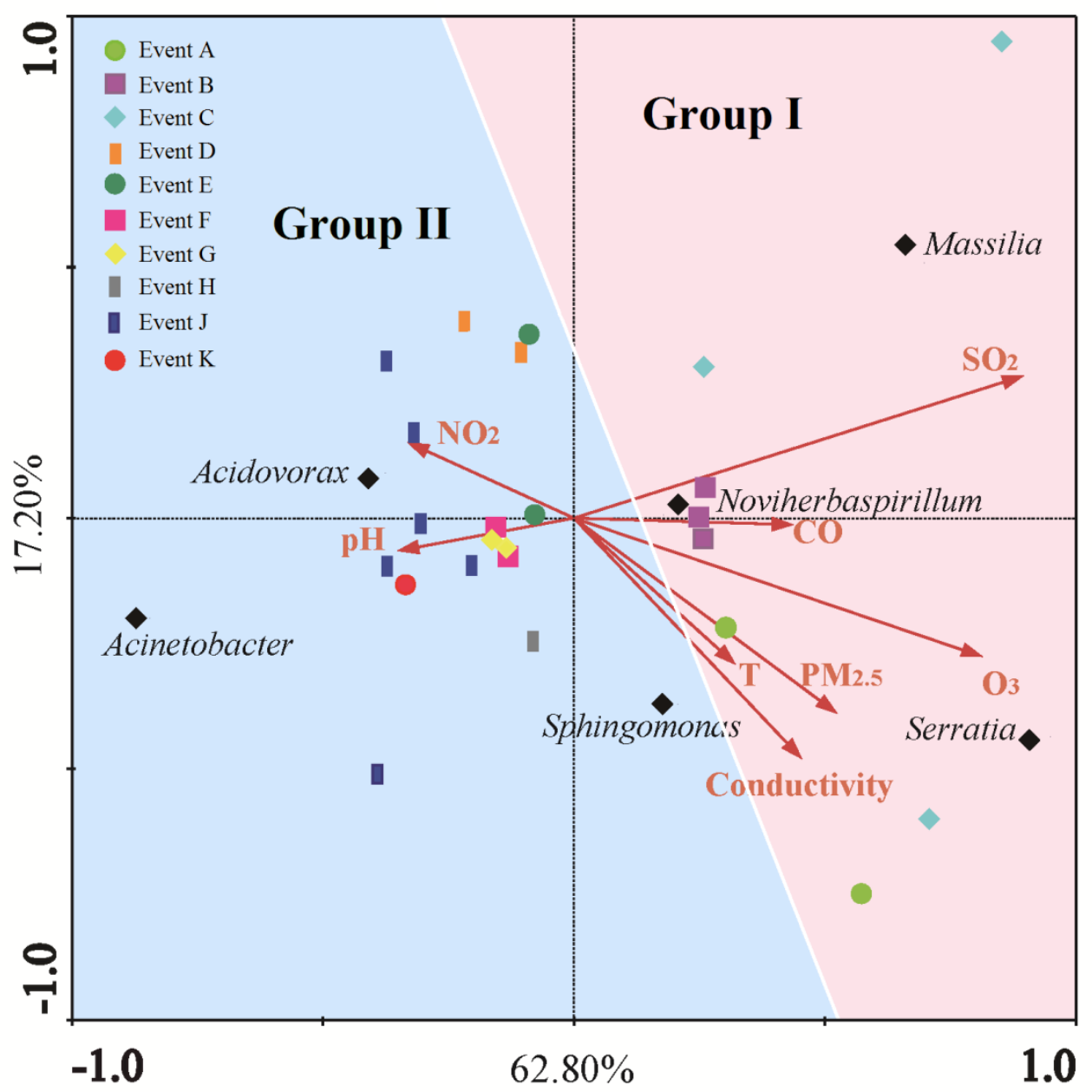

Figure 5 